\title{
U.S. Manufacturing and the Importance of International Trade: It's Not What You Think
}

\author{
Kevin L. Kliesen and John A. Tatom
}

\begin{abstract}
The public often gauges the strength of the U.S. economy by the performance of the manufacturing sector, especially by changes in manufacturing employment. When such employment declines, as has been the trend for many years, it is often assumed to be evidence of the slow death of U.S. manufacturing and an associated rise in imports. This article outlines key trends in U.S. manufacturing, especially the strong performance of manufacturing output and productivity, and their connection to both exports and imports. The authors use ordinary regression, causality, and cointegration analyses to provide empirical evidence for the positive role of imports in boosting manufacturing output. Policies to bolster exports at the expense of imports would significantly harm U.S. manufacturing. (JEL O4, F4, E3)
\end{abstract}

Federal Reserve Bank of St. Louis Review, January/February 2013, 95(1), pp. 27-49.

$\mathbf{T}$ he public and economic commentators often gauge the strength of the U.S. economy by the quantity of automobiles, airplanes, and other manufactured goods produced over any given period of time. This sentiment perhaps harkens back to the nation's leadership in the Second Industrial Revolution, when the mass production of consumer and industrial goods flourished. This rapid growth spurred a migration in the workforce from the farm to the factory. In the past 50 years, though, the share of the nation's employees in manufacturing has steadily declined. Just after World War II, employees in manufacturing represented slightly less than half of the total number of employees in private industry. This share has since declined to about 11 percent today. Manufacturing employment peaked in June 1979 at around 20 million and then fairly steadily declined to about 11 million in January 2010.

To the layperson, the increasingly smaller share of U.S. employees in manufacturing is a cause for concern. In recent years, such concern may have been exacerbated by the large-scale movement of domestic production of certain goods to lower-wage countries such as China or Mexico. Affected industries that readily come to mind are textiles, furniture, and certain electronic goods (e.g., televisions). The popular consensus is that manufacturing employment trends reflect an absolute decline in manufacturing output and the notion that America no longer pro-

Kevin L. Kliesen is a business economist and research officer at the Federal Reserve Bank of St. Louis. John A. Tatom is president and chief executive officer of Thoroughbred Economics. The authors thank Linpeng Zheng and Lowell Ricketts for research assistance.

(c) 2013, The Federal Reserve Bank of St. Louis. The views expressed in this article are those of the author(s) and do not necessarily reflect the views of the Federal Reserve System, the Board of Governors, or the regional Federal Reserve Banks. Articles may be reprinted, reproduced, published, distributed, displayed, and transmitted in their entirety if copyright notice, author name(s), and full citation are included. Abstracts, synopses, and other derivative works may be made only with prior written permission of the Federal Reserve Bank of St. Louis. 


\section{Kliesen and Tatom}

duces tangible goods. 1 In this view, imports are bad because they represent the offshoring of domestic jobs and the death of U.S. manufacturing.

The most recent recession reinforced the death-of-manufacturing view for many analysts. Manufacturing employment peaked in December 2007 and fell by over 2 million jobs by January 2010. Industrial production declined by about 21 percent during the recent recession (December 2007 to June 2009, according to the National Bureau of Economic Research). This decrease was much larger than in the average recession (6.7 percent). The recovery period has also been unusual. Typically, deep recessions are followed by strong recoveries, but real gross domestic product (GDP) growth during the current recovery has been weaker than normal. 2 Nonetheless, the manufacturing sector has enjoyed a fairly robust recovery. Exports have been a key factor fueling the strong recovery in manufacturing. Moreover, some anecdotal evidence has suggested that increasing costs overseas, such as in China, have spurred some manufacturers to return part of their foreign production to domestic facilities. This development has been termed "onshoring."

Accordingly, many policymakers have advanced the idea that exports are one of the best elixirs for the manufacturing sector. $\underline{3}$ This notion seems perfectly reasonable, since slightly more than 70 percent of U.S. exports are manufactured goods. However, the manufacturing sector also depends heavily on imported intermediate products.

This article outlines key trends in the U.S. manufacturing industry, especially the outstanding performance of manufacturing output and productivity, and then discusses their connection to international trade, both exports and imports. In particular, one of our key messages is that, perhaps contrary to conventional wisdom, imports of manufactured goods are extremely important for the manufacturing sector. Specifically, imports of intermediate materials contribute significantly to the industry's strong rate of productivity growth. Exports alone do not exert such a positive influence. Thus, any attempts to bolster exports at the expense of imports, including by lowering the value of the dollar, would significantly harm the U.S. manufacturing sector, the nation's productivity, and ultimately, long-term living standards. In addition, the recent recession, recovery, and expansion reinforce the long-term evidence that (i) U.S. manufacturing continues to expand robustly and (ii) the weakness in manufacturing employment reflects relatively rapid productivity growth, not the slow death of manufacturing. The final section of the article provides empirical support for the positive role of imports in boosting U.S. manufacturing output.

\section{KEY CHARACTERISTICS OF THE U.S. ECONOMY AND THE MANUFACTURING SECTOR}

As in most advanced economies, the service sector accounts for the largest share of output and employment in the United States. However, key segments in the service sector depend importantly on manufactured goods, especially those related to information processing. At the same time, key innovations developed by firms in the manufacturing sector have been adopted by service-sector firms, enabling them to achieve substantial gains in efficiency and productivity. For example, research has found that big-box retailers such as Wal-Mart and Target have improved the nation's productivity by significantly increasing the efficiency of the supply chain 


\section{Figure 1}

\section{Manufacturing Corporations by Asset Size}

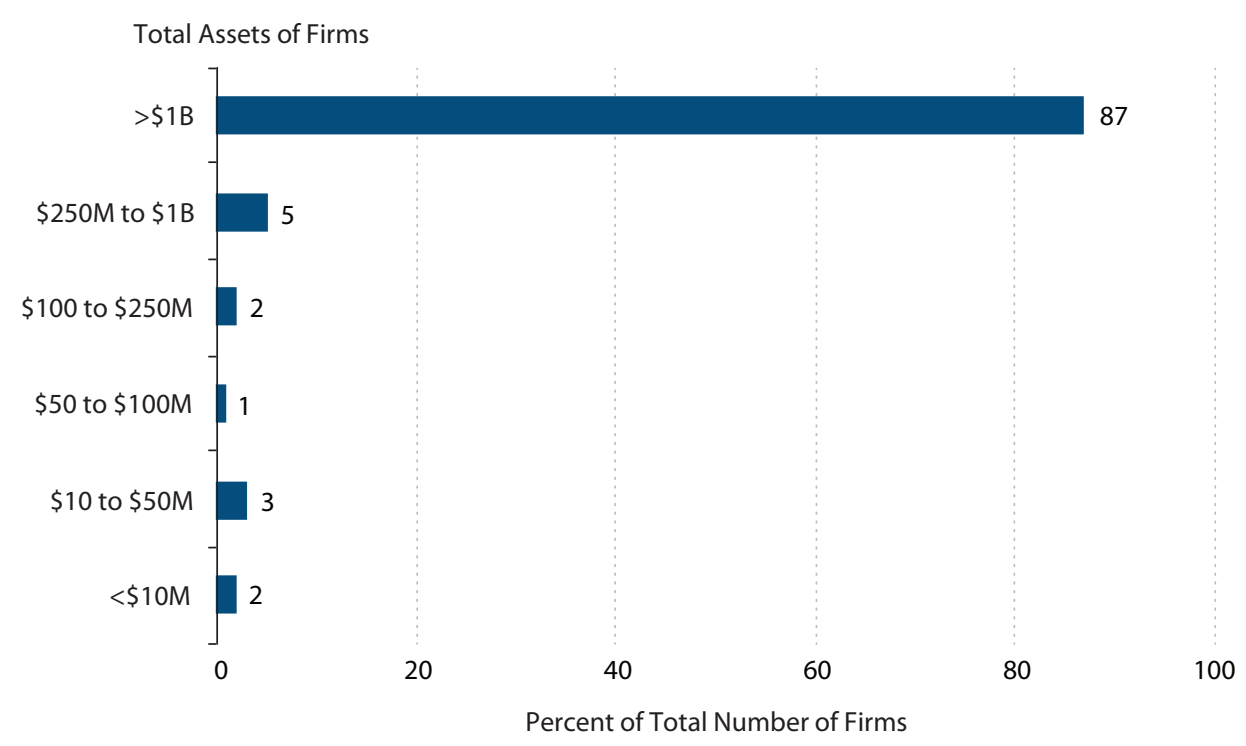

SOURCE: Bureau of the Census, Quarterly Financial Report, 2012:Q1.

from manufacturer to retailer. ${ }^{4}$ This supply chain revolution-termed "just in time" inventorieswas started by Toyota, a large global manufacturer.

Each quarter, the U.S. Census Bureau surveys a subset of the nation's manufacturing, mining, trade, and selected service industries. The results are reported in its Quarterly Financial Report (QFR). In the first quarter of 2012, the Census Bureau surveyed 7,856 manufacturing firms from an estimated population of 137,770 firms. Most people probably believe that the typical U.S. manufacturing firm is a large multinational conglomerate like Toyota, Boeing, or Caterpillar. And indeed, Figure 1 indicates that 87 percent of assets are held by firms with assets in excess of $\$ 1$ billion; but these firms make up only 9.8 percent of the total number of manufacturing firms. On the other end of the spectrum, 3,509 (45 percent) of the sampled firms had assets of less

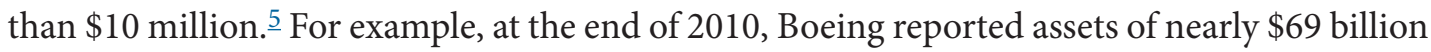
on its consolidated balance sheet, while Caterpillar reported assets of $\$ 64$ billion. $\underline{6}$ In short, the U.S. manufacturing sector is much like the U.S. commercial banking sector. That is, very large firms account for the lion's share of assets, but there is a large number of very small firms that account for a small percentage of industry assets.

A second characteristic of the U.S. manufacturing sector is its inherent volatility compared with the provision of services. As seen in Figure 2, the four-quarter growth of production in the manufacturing sector typically increases much more during recoveries and expansions and falls by much more during recessions. In fact, the most recent recession is unusual because of the depth of the decline in manufacturing output (17.4 percent) and because it was the first time in 50 years that real service output declined during a recession. Despite the huge drop in manufac- 


\section{Figure 2}

\section{Real Services Output and Manufacturing Industrial Production}

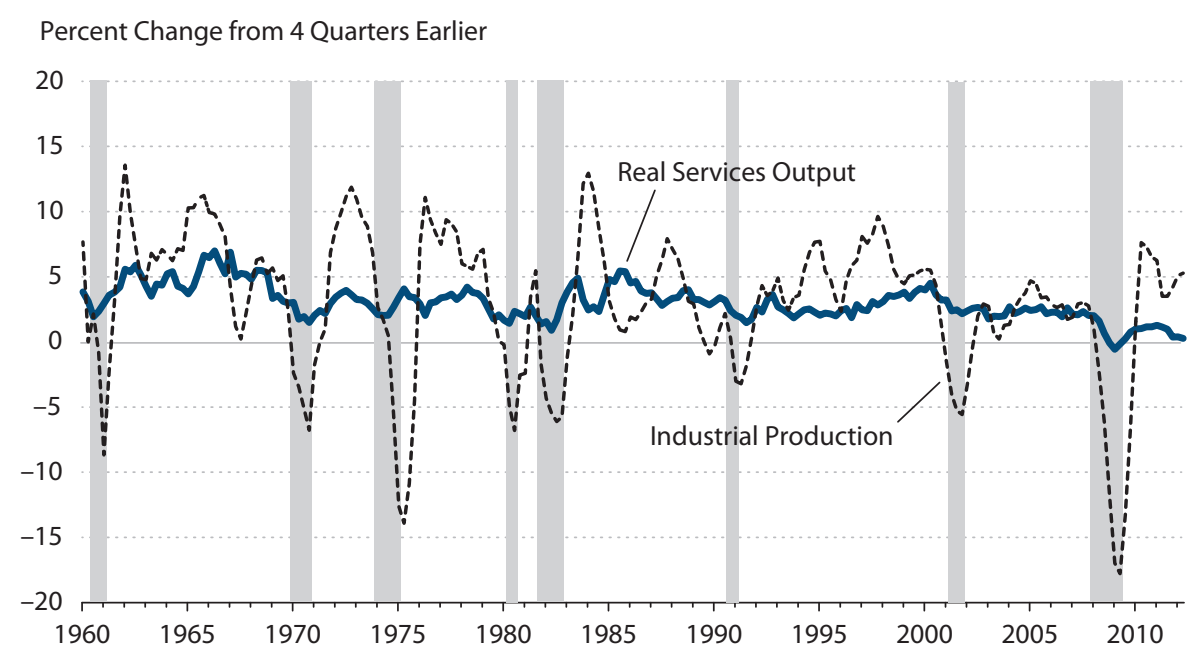

NOTE: Shaded areas indicate recessions as dated by the National Bureau of Economic Research.

SOURCE: Department of Commerce (Bureau of Economic Analysis) and Board of Governors of the Federal Reserve System.

\section{Figure 3}

\section{Labor Productivity Growth (1987-1995, 1996-2012)}

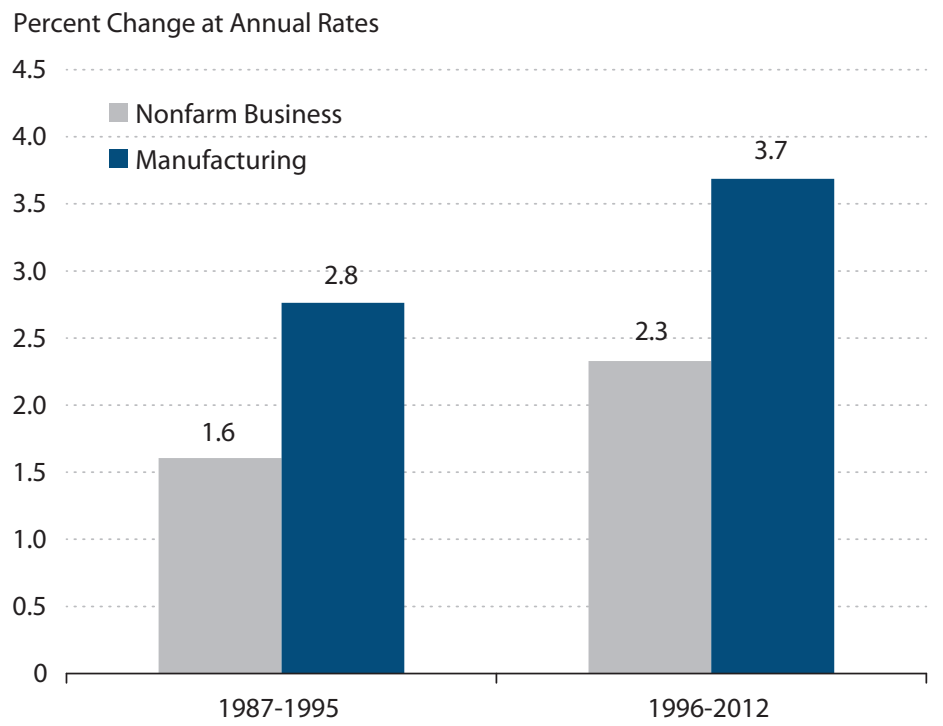


turing output in the most recent recession, its volatility has continued a decline that began in 1983-a period known as the Great Moderation. Since 1983, the standard deviation of the growth of manufacturing output has averaged 4.9 percent, while the standard deviation of the growth of service output has averaged 1.2 percent. This absolute and relative volatility compares with 6 percent and 1.4 percent, respectively, for the period from 1960 to 1983.

A third key characteristic of the manufacturing sector is its relatively high rate of labor productivity growth compared with all other nonfarm businesses. Figure 3 plots the annualized growth rate of labor productivity in the manufacturing and nonfarm private business sectors for the 1987-95 and 1996-2012 periods. We choose 1995 as the breakpoint since there appears to have been a trend break in the data stemming from the information and communications technology revolution. ${ }^{7}$ Also, official labor productivity data for the manufacturing sector begin in 1987. From 1987 to 1995, labor productivity in the manufacturing sector advanced at a 2.8 percent annual rate, 1.2 percentage points faster than in the whole private nonfarm business (NFB) sector. -8 But since manufacturing is included within nonfarm business and there is no separate breakpoint for services, the growth of labor productivity in the service sector was even weaker than in the NFB sector.

Since 1995, productivity in both the manufacturing and private NFB sectors has increased significantly. Still, labor productivity growth in the manufacturing sector (3.7 percent per year) continued to outstrip labor productivity growth in the overall private NFB sector (2.3 percent per year). Indeed, although it is not shown in Figure 3, labor productivity growth in the manufacturing sector has increased at a 4.2 percent annual rate since the trough of the recent recession in the second quarter of 2009. Meanwhile, labor productivity growth in the private NFB sector has slowed to around 1.7 percent per year.

The faster growth of labor productivity in the manufacturing sector relative to the NFB sector has produced two key effects. First, as seen in Figure 4, the share of manufacturing employment has steadily declined since 1939, except for a brief upswing during World War II, while the share of payroll employment in the service sector has increased. For purposes of comparison, Figure 4 also plots the private-sector share of construction employment, the other major category shown. Despite the recent housing boom, the share of employment in the construction sector has been relatively constant over time.

The decline in manufacturing's share of private payroll employment parallels the decline in

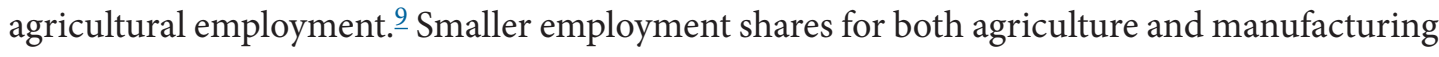
reflect the steady substitution of labor for capital over time and the relatively rapid rates of productivity growth in each sector. Figure 5 indicates that capital spending is strongly positively associated with the growth of manufacturing output. $\underline{10}$ Business expenditures on equipment and software are not a key driver of increases in manufacturing output. Rather, the causality appears to run from manufacturing output to business investment, so strong growth of capital spending is generally seen as a signal of strong output growth. However, capital spending is not passive in an economic sense. Importantly, economic theory suggests that output per hour (labor productivity) is a function of a firm's (or a nation's) capital-to-labor (K-L) ratio.

The manufacturing industry has steadily increased its K-L ratio over time at a faster rate than has the service sector. Figure 6 plots the K-L ratio in the nonfarm, nonmanufacturing and manufacturing sectors since 1939. From 1948 to 1995, the K-L ratio increased at a 2.7 percent 


\section{Kliesen and Tatom}

\section{Figure 4}

Private Employment Shares in the Service-Producing and Manufacturing Sectors

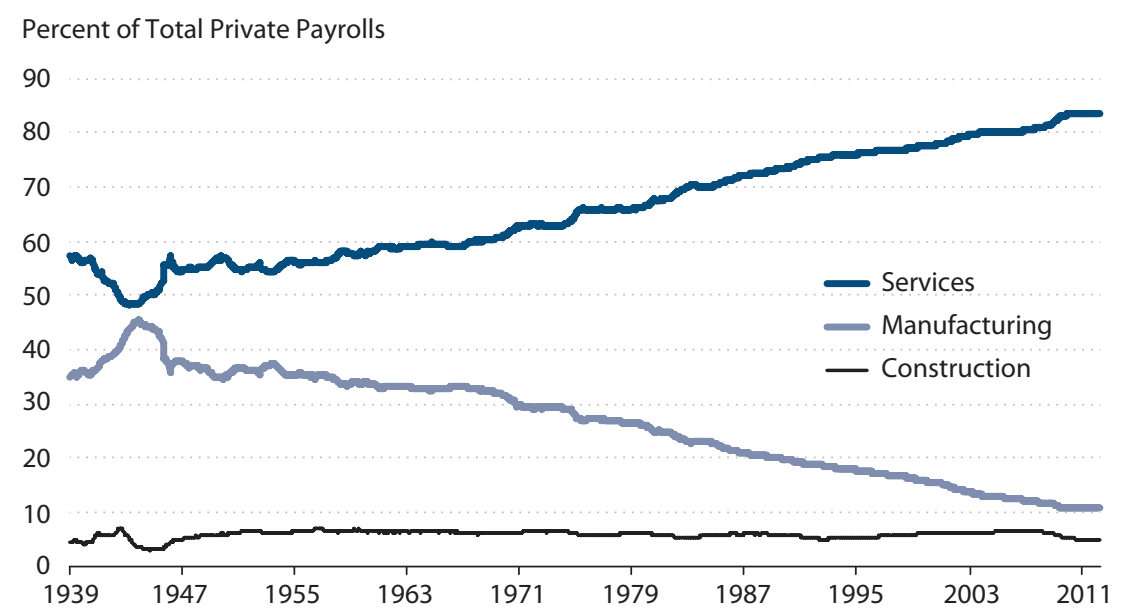

Figure 5

\section{Growth of Manufacturing Production and Equipment and Software Investment}

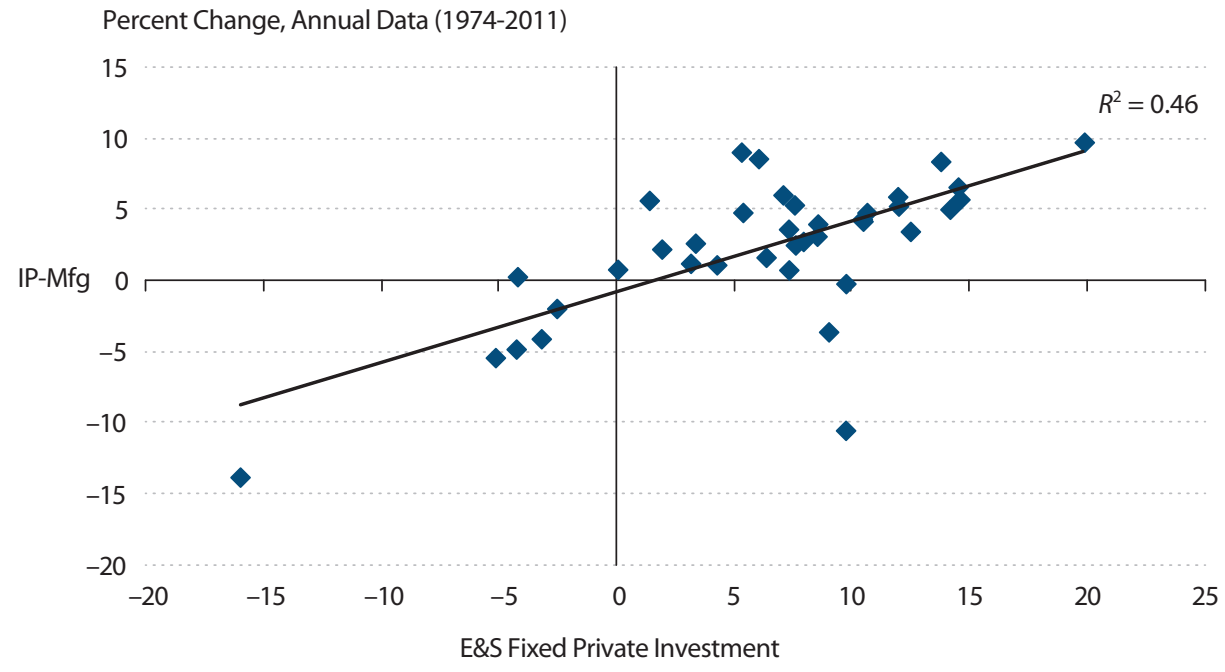

NOTE: E\&S, equipment and software; IP-Mfg, industrial production index for manufacturing output. SOURCE: Federal Reserve Board of Governors and Bureau of Economic Analysis. 


\section{Figure 6}

\section{Capital-to-Labor Ratios in the Manufacturing and the Nonfarm, Nonmanufacturing Sectors}

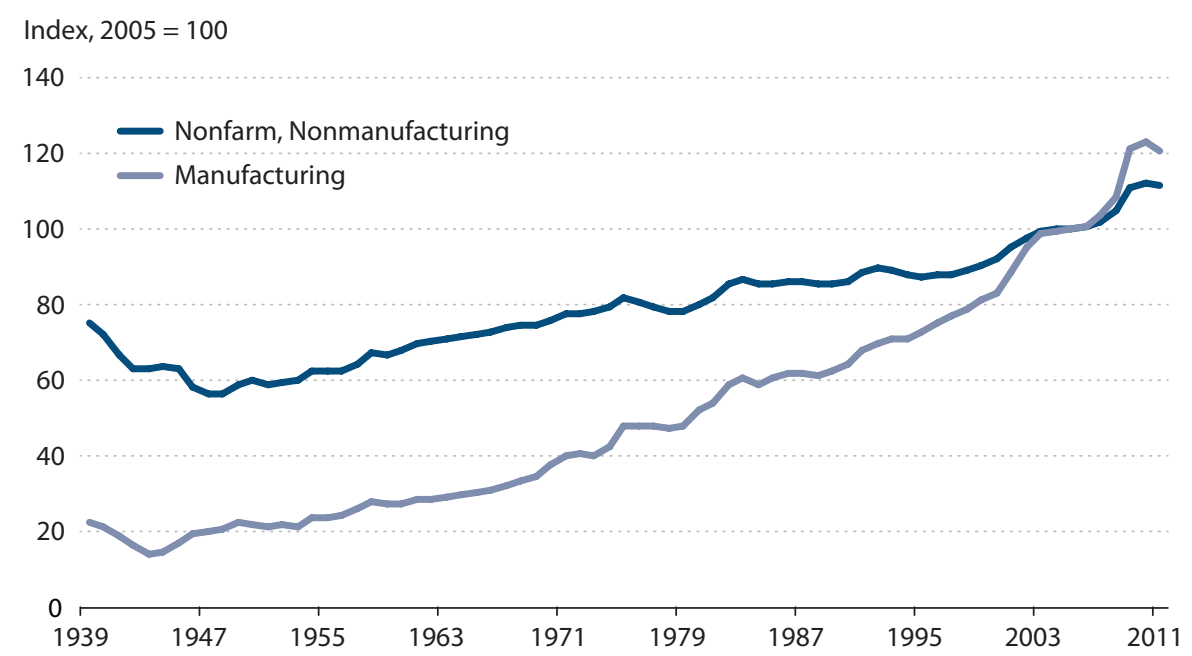

\section{Figure 7}

\section{Industry Rates of Return on Capital (1999-2010)}

Percent, Average of Years Indicated

20

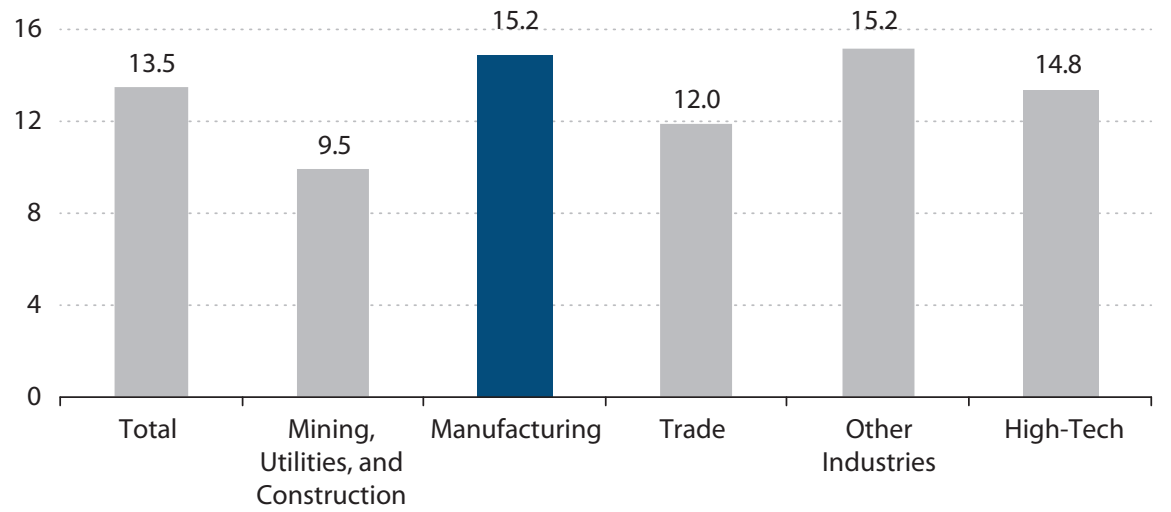




\section{Kliesen and Tatom}

annual rate in the manufacturing sector but by only about 1 percent in the nonfarm, nonmanufacturing sector. Since 1995, the growth rate of the K-L ratio has increased in both sectors, although by a bit more in the manufacturing sector. Since 1995, the K-L ratio has increased at a 3.2 percent annual rate in the manufacturing sector and at a 1.5 percent rate in the nonfarm, nonmanufacturing sector.

A declining share of labor input and robust growth of manufacturing output and productivity suggest a relatively strong rate of return on capital in the manufacturing sector. Indeed, this is what the data show. The Bureau of Economic Analysis (BEA) has released annual rates of return in nonfinancial industries since 1999. Figure 7 shows the average annual rates of return from 1999 to 2010 for total nonfinancial industries and mining, utilities, and construction; manufacturing; retail and wholesale trade; high-technology; and all other industries. $\frac{11}{}$ As the figure shows, the rate of return on capital for manufacturing (15.2 percent per year) has exceeded the total nonfinancial industries (13.5 percent) by a sizable margin. Over this period, rates of return in manufacturing have exceeded all industries except the Other Industries group, where the rate of return is the same.

\section{INTERNATIONAL INFLUENCES}

Manufactured durable and nondurable goods comprise the largest share of U.S. exports. In 1929, goods exports were nearly 90 percent of total exports; by 2011 they had declined to about 71 percent. In 2011, goods exports were $\$ 2.1$ trillion. Service exports were a little more than $\$ 600$ billion; although up significantly over time, as a share of total exports, service exports are still only about 30 percent of total exports.

The composition of goods exports has also changed over time. Since reaching a trough of 25 percent in 1933, durable goods exports as a share of total exports rose on net over the next several decades, reaching a peak of 52 percent in 2000 (Figure 8). Over that same period, nondurable goods exports as a share of total exports declined from 60 percent to less than 20 percent. Since 2000, however, the share of durable goods exports has declined to 43 percent of total exports, but this share is still within the 40 to 50 percent range experienced over most of the post-World War II period. By contrast, the share of nondurable goods exports has risen to about 28 percent of total exports. As seen in Figure 8, exports of nondurable goods nearly equaled the share of services exports in 2011. The increased share of nondurable exports has been in industrial supplies and materials and agricultural products.

Since most goods exports are manufactured products, it seems reasonable to conclude - as some policymakers evidently have-that the health of the U.S. manufacturing sector depends to a significant extent on the global demand for manufactured goods and this, in turn, depends on changes in the exchange rate. One key development in this regard in recent years has been the significant increase in U.S. manufactured goods exports to China. Since 1990, U.S. goods exports to China have increased by more than 20 -fold (Figure 9). In contrast, U.S. goods exports to the rest of the world have increased a little more than threefold. However, the correlation between the growth of manufacturing output and real goods exports is essentially zero. Figure 10 indicates a statistically insignificant positive correlation, an $R$-squared value of 0.05 from 1974 to 2011. Perhaps even more counterintuitive to some is the correlation between the 


\section{Figure 8}

\section{U.S. Export Shares by Type}

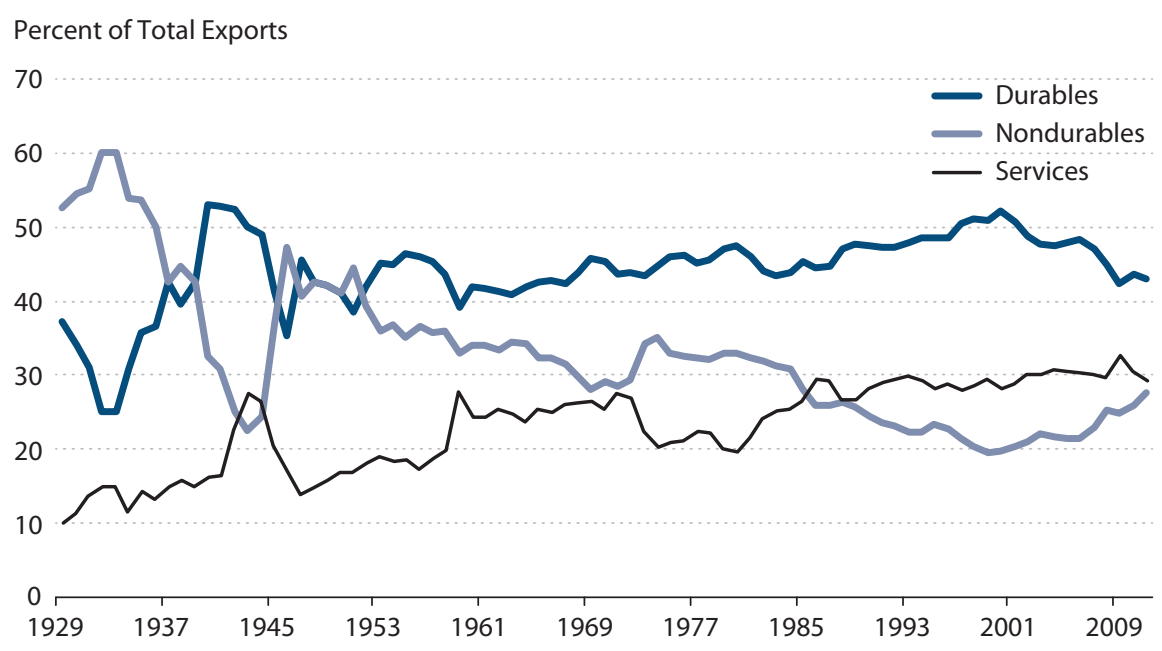

\section{Figure 9}

\section{U.S. Export of Goods}

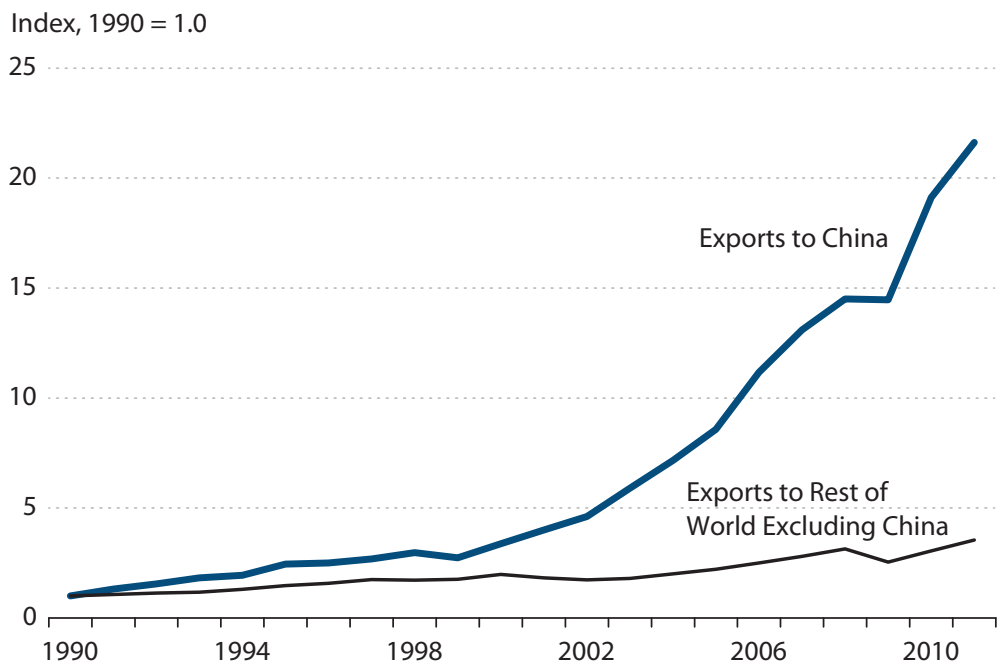

SOURCE: Department of Commerce (Bureau of the Census) and Council of Economic Advisers. 


\section{Figure 10}

\section{Growth of Manufacturing Production and U.S. Real Goods Exports}

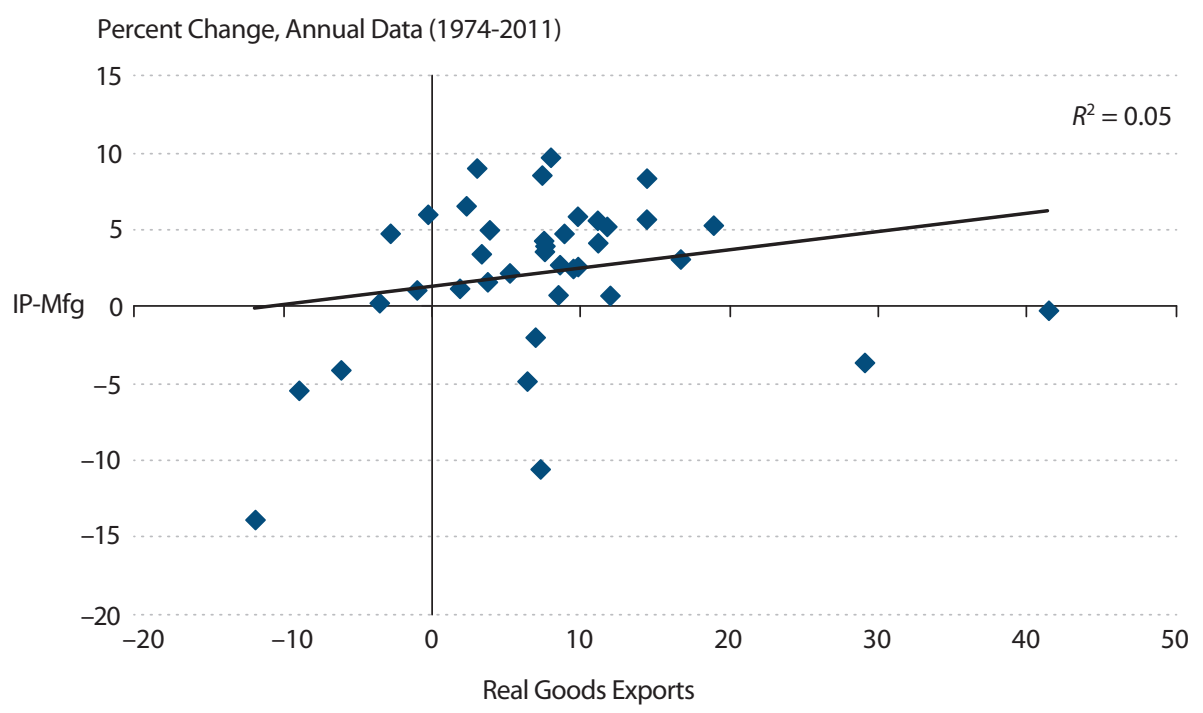

NOTE: IP-Mfg, industrial production index for manufacturing output.

SOURCE: Federal Reserve Board of Governors and Bureau of Economic Analysis.

growth of real manufacturing output and the real value of the U.S. trade-weighted dollar; as shown in Figure 11, it is also essentially zero with an $R$-squared value of 0.01 .

\section{Do Imports Matter More than Exports?}

As noted previously, manufactured goods exports constitute the dominant share of U.S. exports. Moreover, exports of durable goods such as automobiles, construction equipment, or airplanes are the largest component of total U.S. exports. But what about imports? According to the Boeing Company, non-U.S. suppliers provide roughly 30 percent of the content of its new 787 Dreamliner. $\underline{12}$ These include suppliers from Belgium, Canada, France, Italy, South Korea, the United Kingdom, and other countries. $\frac{13}{}$ From this standpoint, then, imports are a key part of the manufacturing supply chain. Indeed, as shown in Figure 12, real goods imports have risen appreciably faster than real goods exports, as shares of manufacturing output. In 2011, the share of real goods imports exceeded the share of real goods exports by about 34 percentage points. An increasing percentage of goods imports, perhaps not surprisingly, is from China and the expense of imports from other Pacific Rim countries, such as Japan. In 1992, the share of U.S. goods imports from China was about 5 percent and the share from other Pacific Rim countries was 34 percent. By 2011, China's share had risen to 18 percent and the share of imports from other Pacific Rim countries had declined to 14 percent. Not surprisingly then, the $R$-squared value between the growth of manufacturing output and of real goods imports is exceptionally high, 0.81 (Figure 13), and much stronger than that between the growth of manufacturing output and of real goods exports. 


\section{Figure 11}

Growth of Manufacturing Production and the Real Value of the U.S. Dollar

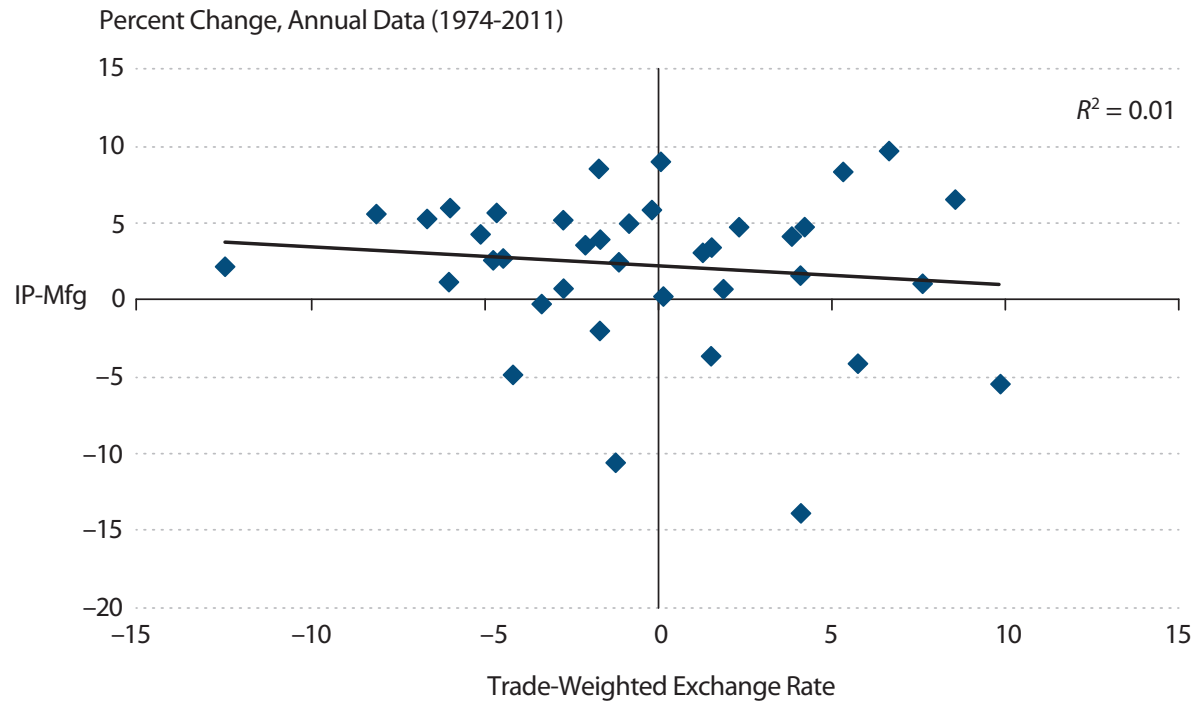

NOTE: IP-Mfg, industrial production index for manufacturing output.

SOURCE: Federal Reserve Board of Governors.

Figure 12

\section{Real Goods Exports and Imports as a Percent of Real Manufacturing Value Added}

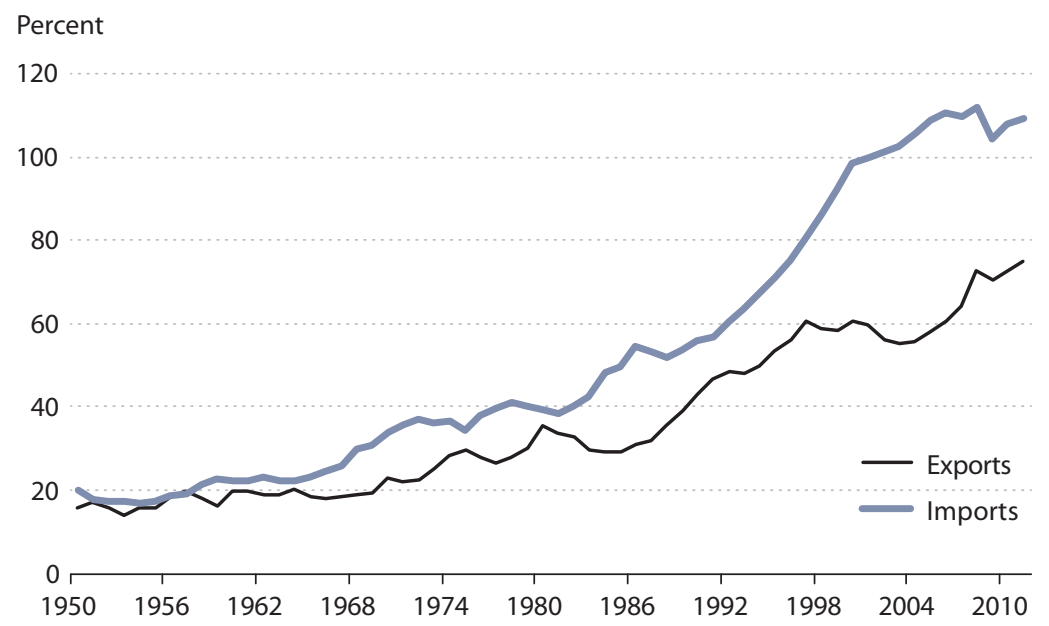




\section{Figure 13}

\section{Growth of Manufacturing Production and U.S. Real Goods Imports}

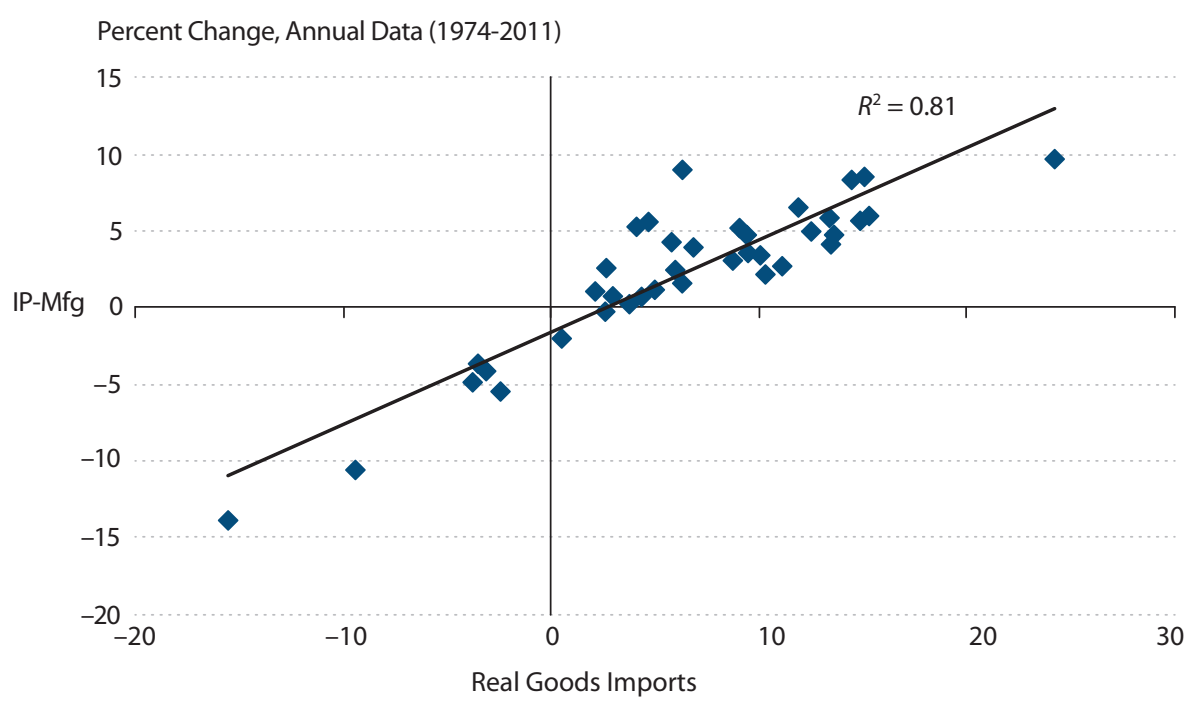

NOTE: IP-Mfg, industrial production index for manufacturing output.

SOURCE: Federal Reserve Board of Governors and Bureau of Economic Analysis.

Houseman et al. (2011) argue that manufacturing output and productivity have been affected by "offshoring bias," which provides an alternative reason for the strong correlation between imports and manufacturing output. Essentially, they argue that official statistics misstate price developments for intermediate materials that have moved from domestic production to foreign production. They show that prices of imports from developing countries have lower prices for intermediates than measured. Overstating the intermediary import prices tends to understate real imports and thereby the contribution of imports to output. As a result, they argue, total factor productivity, output, and labor productivity in manufacturing are biased upward. As long as true real imports are positively correlated with measured imports, this bias imparts an upward bias in the correlation between manufacturing output and imports. However, Houseman et al. estimate that the upward bias in output growth is 0.2 to 0.5 percentage points from 1997 to 2007, which is much smaller than the estimated contribution of imports to manufacturing output growth estimated below. While their analysis has conceptual and theoretical significance, its potential role in the story of the contribution of imports to manufacturing output here is minor.

\section{FURTHER EMPIRICAL ANALYSIS}

The finding that the growth of manufacturing output is strongly correlated with goods imports and not with goods exports is informative. It suggests that policies designed to restrict imports or artificially raise their costs would have adverse effects for U.S. manufacturers. Thus, if the trade-weighted value of the U.S. dollar were to decline, it is not definite that manufacturers 
would benefit to the extent that many believe. $\stackrel{14}{ }$ For example, a decline in the value of the dollar would lower the price of U.S. manufactured goods to foreign buyers, which would increase U.S. goods and services exports, all else equal. At the same time, however, a weaker dollar would raise the dollar price of imported goods and services in the United States. Thus, all else equal, Boeing would pay more for imports of supplies and materials used to construct its 787 Dreamliner, which would increase the price of the Dreamliner, thereby reducing sales and therefore profits.

To formally test the hypothesis that imports matter as much as or more than exports to the growth of manufacturing output, this section presents the results of an ordinary least squares regression analysis, a statistical test to assess causality, and an analysis of cointegration of manufacturing output. In the regression analysis we model the quarterly growth of manufacturing output from 1973:Q2 to 2011:Q4. 15 Our initial specification is that the growth (log change) of real manufacturing output is a function of the growth (log change) of (i) real GDP, (ii) foreign real GDP, (iii) the real trade-weighted value of the U.S. dollar, (iv) real energy prices, (v) real goods exports, and (vi) real goods imports. The specification also controls for the business cycle by including the first difference of the unemployment rate (vii) in the United States and (viii) abroad, although the latter was not statistically significant at a conventional 5 percent significance level and was dropped from the reported results. We also include a constant and a lagged value of the dependent variable. We also examined lags of the independent variables, but none were statistically significant.

In this specification, the coefficients on U.S. and foreign real GDP are expected to be positive; faster domestic and foreign growth would increase the demand for U.S. manufactured goods. The coefficients on real goods exports are also expected to be positive, because an increase in goods exports is associated with increased foreign demand for U.S. manufactured goods. Although Figure 13 suggests that faster growth of real goods imports is associated with faster growth of real manufacturing output (a positive sign), it could also be true that faster growth of real goods imports reflects a substitution away from domestic manufactured goods. Thus, in theory, the sign could be negative.

The final three variables - the change in the U.S. unemployment rate, the real exchange rate, and real energy prices-are expected to have negative coefficients. A higher unemployment rate generally indicates a slowing economy and thus weaker demand for U.S. manufactured goods. An appreciation of the dollar, for reasons noted previously, would also be expected to reduce the foreign demand for U.S. manufactured products. Finally, higher real oil prices not only increase the price of manufactured goods (higher input costs and lower productivity), but they also tend to reduce the growth rate of aggregate economic activity, which would also reduce the demand for manufactured goods.

Table 1 presents the results for our hypothesized specification. The first column shows the results for the specification described above. Faster growth of domestic output (income), as expected, raises the growth of manufacturing output, and the coefficient is relatively large (0.79) and statistically significant. Similarly, because a higher U.S. unemployment rate signals a slower pace of economic activity, we anticipated that the coefficient for the change in unemployment would be negative; it is, and it is statistically significant. The growth of foreign output has a positive and significant effect on domestic manufacturing output, as expected. 


\section{Table 1}

Predicting the Growth Rate of U.S. Manufacturing Output

\begin{tabular}{|c|c|c|c|}
\hline \multirow[b]{3}{*}{ Independent variables } & \multicolumn{3}{|c|}{$\begin{array}{l}\text { Dependent variable: } \\
\text { Log change of U.S. manufacturing output }\end{array}$} \\
\hline & \multicolumn{3}{|c|}{ Model specification } \\
\hline & (1) & (2) & (3) \\
\hline Constant & $\begin{array}{c}-1.49^{* *} \\
(0.004)\end{array}$ & $\begin{array}{c}-1.47^{* *} \\
(0.004)\end{array}$ & $\begin{array}{r}-1.53^{* *} \\
(0.003)\end{array}$ \\
\hline Lagged dependent variable & $\begin{array}{c}0.10^{*} \\
(0.038)\end{array}$ & $\begin{array}{c}0.10^{*} \\
(0.039)\end{array}$ & $\begin{array}{c}0.11^{*} \\
(0.024)\end{array}$ \\
\hline U.S. real GDP & $\begin{array}{r}0.79 * * \\
(0.000)\end{array}$ & $\begin{array}{r}0.78^{* *} \\
(0.000)\end{array}$ & $\begin{array}{r}0.77^{* *} \\
(0.000)\end{array}$ \\
\hline Foreign real GDP & $\begin{array}{c}0.35^{*} \\
(0.024)\end{array}$ & $\begin{array}{c}0.32^{*} \\
(0.029)\end{array}$ & $\begin{array}{r}0.38^{* *} \\
(0.010)\end{array}$ \\
\hline Unemployment rate (\%) & $\begin{array}{r}-31.17^{* *} \\
(0.000)\end{array}$ & $\begin{array}{r}-31.22^{* *} \\
(0.000)\end{array}$ & $\begin{array}{r}-30.56^{* *} \\
(0.000)\end{array}$ \\
\hline Real value of the dollar & $\begin{array}{c}0.01 \\
(0.692)\end{array}$ & & \\
\hline Real energy prices & $\begin{array}{l}0.02 \\
(0.062)\end{array}$ & $\begin{array}{l}0.02 \\
(0.076)\end{array}$ & \\
\hline Real imports & $\begin{array}{c}0.16^{* *} \\
(0.000)\end{array}$ & $\begin{array}{c}0.16^{* *} \\
(0.000)\end{array}$ & $\begin{array}{r}0.15^{* *} \\
(0.000)\end{array}$ \\
\hline Real exports & $\begin{array}{l}-0.01 \\
(0.664)\end{array}$ & & \\
\hline Adjusted $R^{2}$ & 0.79 & 0.79 & 0.79 \\
\hline Durbin-Watson & 1.93 & 1.95 & 1.96 \\
\hline Standard error of regression & 3.36 & 3.34 & 3.37 \\
\hline
\end{tabular}

We also hypothesized that the coefficient for the growth of real energy prices and the value of the dollar would be negative. In each instance, however, the coefficient is positive, but very small. As Figure 11 shows, the coefficient for the change in the real value of the dollar is essentially zero and not significant. Similarly, the coefficient for growth of real energy prices is not statistically significant at a conventional level. The final two independent variables for the first model specification are the trade variables. Perhaps surprisingly, the growth of exports does not help to explain the growth of industrial production, as the coefficient is essentially zero and not significant. Hence, those who argue that enhancing U.S. goods exports should be a key strategy for boosting the health of the manufacturing sector may be disappointed. However, goods imports do appear to matter a great deal for the growth of manufacturing output. The coefficient is positive and highly significant, which must surprise critics of outsourcing, offshoring, and imports in general.

Table 1 reports two additional model specifications. The second specification drops the insignificant real value of the dollar and export variables from the first specification; the energy 
price variable is not significant, but since it is close to significance it is not dropped until the third specification. In the second specification, the coefficients of the remaining variables are essentially the same, as is their significance and the fit of the equation. This is to be expected, given the small size and insignificance of the two omitted variables. In the third specification where the real energy price measure is omitted, the results are essentially the same as in the second specification.

To summarize, we find some positive persistence in manufacturing output growth. We also find, perhaps not surprisingly, that domestic and foreign growth rates of real GDP matter significantly to the growth of manufacturing output, but the effect of the growth of U.S. output is much larger. This fact is reinforced by our finding that changes in the unemployment rate also matter significantly and negatively. Finally, we find, perhaps contrary to the conventional wisdom, that faster growth of U.S. exports does not seem to bear any relationship to the growth of U.S. manufacturing output. However, since the foreign demand for U.S.-produced goods probably depends to a significant extent on the growth of foreign income and the price of U.S. manufactured goods, the export effect could be captured by the influence of the foreign output variable, which is highly significant. This could also explain why the real exchange rate is insignificant.

However, deleting foreign real GDP growth from the last two specifications in Table 1 (not shown) does not alter the significance of real export growth or, in the second specification, the growth of the real exchange rate. In the first specification, the coefficient on the growth rate of exports, without the foreign real GDP variable, is $0.003(p=0.09)$ and for the growth rate of the real exchange rate is $0.004(p=0.13)$. In the third specification, the coefficient on the growth rate of exports is $0.019(p=0.67)$. Thus, the results for the effect of real export growth, or the real exchange rate, do not occur because of the correlation between export growth and foreign real GDP growth.

Perhaps the biggest surprise to those who stress the importance of exports is the finding that imports of manufactured goods seem to be much more important to the U.S. manufacturing sector. But why? Figure 14 helps to explain the answer. Eldridge and Harper (2010), working with BEA data, use a growth accounting exercise to estimate the contributions to manufacturing sector productivity growth from 1997 to 2006 . Over this period, productivity growth averaged nearly 4 percent per year. The contribution from multifactor (or total factor) productivity accounted for a little less than half of this growth. Recall that multifactor productivity accounts for changes in productivity not accounted for by capital and labor services. In a traditional growth accounting model, intermediate inputs are not explicitly modeled. As a result, total output is equal to value added (real GDP originating). $\underline{16}$

As seen in Figure 14, though, Eldridge and Harper (2010) also attempt to account for intermediate materials, those produced domestically and those imported from foreign sources. They find that the combined contribution of intermediate materials to manufacturing productivity growth over this period was nearly 1.6 percentage points-almost as large as the contribution from multifactor productivity. But more interesting is their discovery that the contribution from imported intermediate materials was slightly less than 1 percentage point, or nearly 50 percent larger than domestically manufactured intermediate materials. According to Eldridge and Harper, in 1998 nearly 25 percent of intermediates used by the manufacturing sector was imported from foreign sources; but, by 2006, this share had increased to 34 percent. This finding suggests that 


\section{Figure 14}

\section{Contributions of Nonlabor Factor Imputs to the Growth of Labor Productivity in the Manufacturing Sector (1997-2006)}

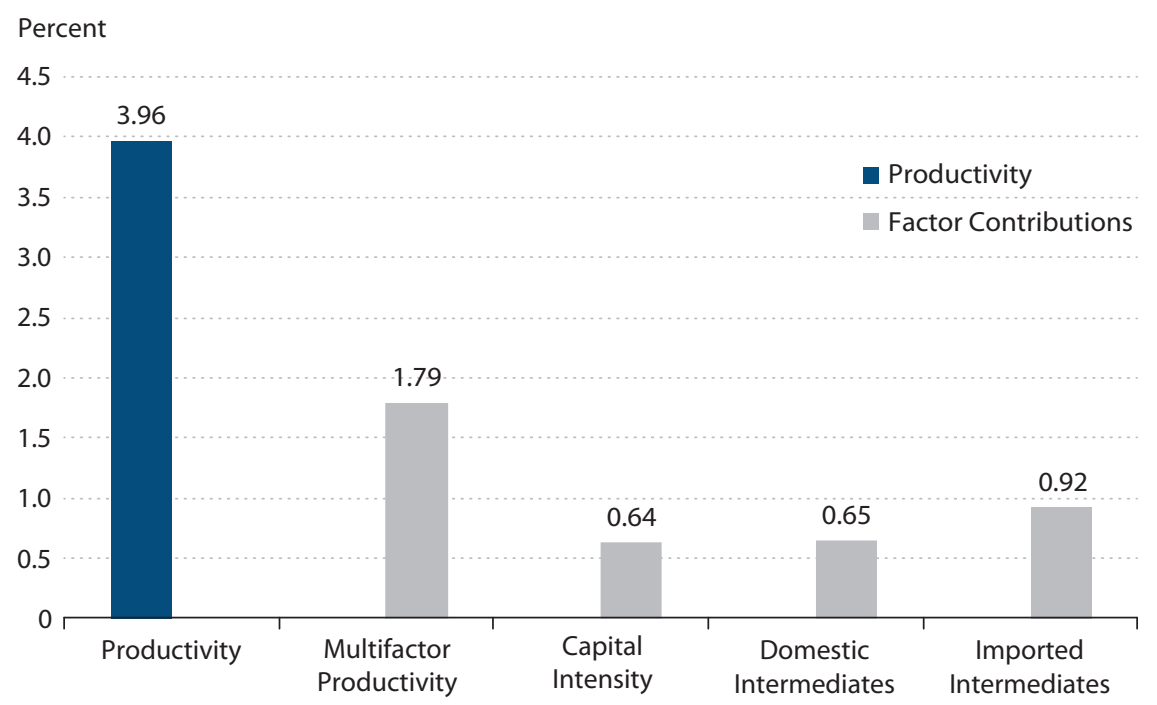

SOURCE: Eldridge and Harper (2010).

the value added from imported intermediates was proportionately much larger than that of domestic intermediates.

Houseman et al. (2011) argue that offshoring bias added 0.2 to 0.5 percent to real manufacturing output growth over the 1997-2007 period. This amount is quite large, but the results in Table 1 suggest that the 6.25 percent import growth over the period contributed 1 percent to manufacturing output growth over this period. Thus their results could account for about 20 to 50 percent of the contribution of imports to real value added growth in manufacturing. This is potentially a large effect, but one that still leaves a large role for the effect of imports on manufacturing output.

From a policy perspective, the importance of intermediate materials to the U.S. manufacturing sector suggests that efforts to either restrict the flow of imports through quotas or raise the price of intermediate materials through tariffs could harm the manufacturing sector. Similarly, to the extent that these intermediate materials are imported from Chinese sources, an appreciation of the renminbi could similarly increase the cost for manufacturers and thus, all else equal, reduce manufacturing output.

\section{Granger Causality Tests}

The next issue is causality, which is examined using Granger causality tests. These tests assess whether past values of real import (or export) growth provide statistically significant explanatory power for the current level of manufacturing output growth when previous values (lags) of manufacturing output growth are also included. If so, manufacturing output growth is 


\section{Table 2}

\section{Granger Causality Testing for Statistical Causality Between the Growth of Goods Imports or Exports and the Growth of Manufacturing Output}

\begin{tabular}{lcc} 
Granger causality test specifications & F-statistic & Probability \\
\hline Import growth (GIMPORTS) and the growth of & & \\
manufacturing output (IPMFG) & & 0.000 \\
Lags: 8 & 11.160 & 0.484 \\
IPMFG does not Granger-cause GIMPORTS & 0.942 & 0.000 \\
GIMPORTS does not Granger-cause IPMFG & & 0.619 \\
Lags: 4 & 21.680 & \\
IPMFG does not Granger-cause GIMPORTS & 0.662 & \\
GIMPORTS does not Granger-cause IPMFG & & 0.006 \\
Export growth (GEXPORTS) and the growth of & & 0.327 \\
manufacturing output (IPMFG) & & \\
Lags: 8 & 2.848 & 0.001 \\
IPMFG does not Granger-cause GEXPORTS & 1.163 & 0.099 \\
GEXPORTS does not Granger-cause IPMFG & & \\
Lags: 4 & 5.253 & 1.989 \\
$\quad$ IPMFG does not Granger-cause GEXPORTS & & \\
GEXPORTS does not Granger-cause IPMFG & & \\
NOTE: The sample period is 1973:Q2 to 2011:Q4. & &
\end{tabular}

said to be Granger-caused by real import (export) growth. It is possible that the regression result for imports in Table 1 could arise because of the effect of output growth on imports instead of the effect of imports on output. A simple test of Granger causality shows that this is the case. The same is true for exports, even though they are not significant in Table 1.

Table 2 shows Granger causality test results for the growth rates of real imports and manufacturing output and the growth rates of real exports and manufacturing output. For each pair of possible relationships-(i) export growth and manufacturing growth and (ii) import growth and manufacturing growth-lags of 8 or 4 past values of the growth rate of the dependent variable and the growth rate of the other variable are used to assess whether the other variable adds statistically significant information.

For imports, the first two specifications in Table 2 (using 8 and 4 lags), the statistically significant $F$-statistic shows that the hypothesis that manufacturing output growth does not Grangercause the growth rate of imports can be rejected. At the same time, the hypothesis that the growth rate of imports does not Granger-cause manufacturing output cannot be rejected. This test suggests that Granger causality runs in one direction-namely, from the growth of manufacturing output to the growth of imports. In other words, past manufacturing output growth helps to improve the prediction of the current growth of real imports. The same is true for the growth rate of exports. The growth rate of exports does not Granger-cause manufacturing output, but the growth rate of manufacturing output Granger-causes the growth rate of exports. These results mean there is a strong, statistically significant temporal ordering. That is, accelerations 


\section{Kliesen and Tatom}

\section{Table 3}

\section{Cointegration Results for Manufacturing Output and Imports}

\section{Cointegrating equation}

$\ln (\mathrm{XM})_{t}-0.401 \ln (\mathrm{IM})_{t}-1.554=\mathrm{e}_{t}$

$(-21.03)$

NOTE: The error term (e) is normally distributed with a zero mean and constant variance. It is the error correction term.

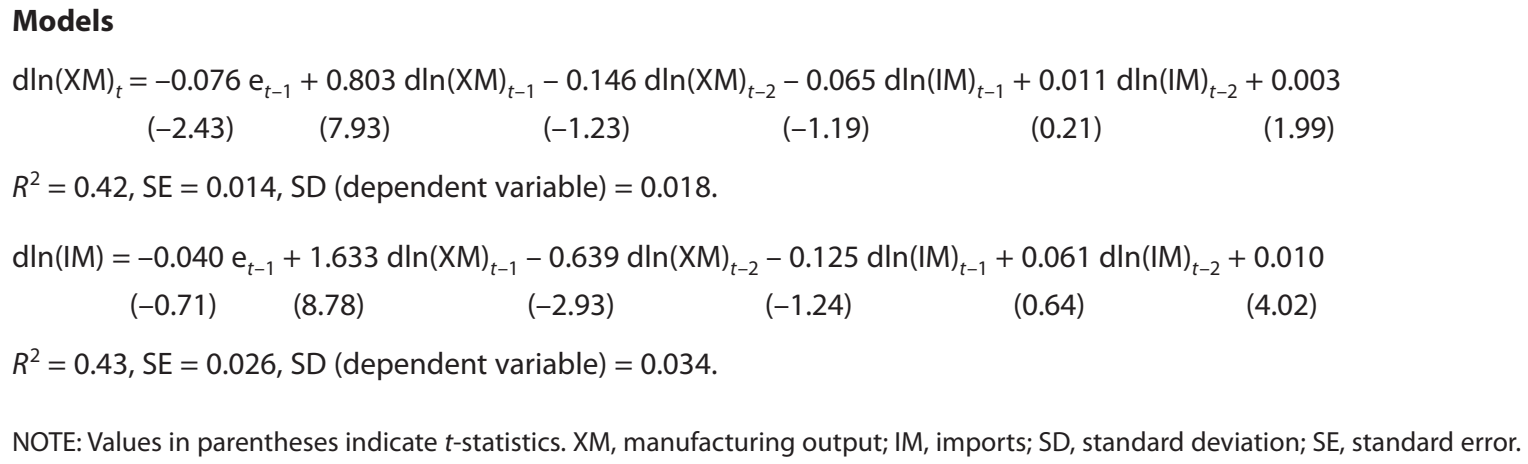

(decelerations) in manufacturing output growth precede significant increases (decreases) in both import and export growth. Attempts to restrict import growth are likely to weaken the growth of manufacturing output because of this linkage between the two measures.

\section{Cointegration Test}

A technical objection to regression analysis is the endogeneity of the independent variables in Table 1, which in ordinary regression analysis should be independent of the dependent variable as well as each other. Table 2 supports causality from manufacturing output to imports, for example. As indicated in the previous discussion, there are other interdependencies among the variables. Stronger evidence of a long-run relationship between imports and manufacturing production is available from cointegration analysis. This approach also accommodates the endogeneity problem. Cointegration analysis allows for mutual interdependence and determines whether long-run relationships exist between measures in addition to the interdependencies.

The Johansen method of testing cointegration is used to test for cointegration between manufacturing output and the significant variables in the last column of Table 1 . Since the unemployment rate is a stationary variable, which means that it varies around a fixed mean over time instead of drifting over time (nonstationary), it is dropped from the potential cointegrating equation. All levels of the measures except the unemployment rate in Table 1 are found to be nonstationary using unit root tests, but their first differences are stationary (not reported here).

None of the unit root tests for the variables has more than one significant lag; most have no significant lags. Therefore, two lags of the variables are included in the dynamic portion of the test equations. Because none of the variables had a zero mean, the test equations include a constant in the cointegration equations. When all variables are included, the coefficient of most measures in the potential cointegration equation is not significant. In particular, the natural 
Kliesen and Tatom

\section{Table 4}

Impulse Response Estimates for Table 3

\begin{tabular}{|c|c|c|c|c|}
\hline \multirow[b]{2}{*}{ Quarters } & \multicolumn{2}{|c|}{$\begin{array}{l}\text { Response of manufacturing output } \\
\text { (XM) }\end{array}$} & \multicolumn{2}{|c|}{$\begin{array}{l}\text { Response of imports } \\
\text { (IM) }\end{array}$} \\
\hline & $\mathrm{XM}$ & IM & XM & IM \\
\hline 1 & 0.014 & 0.000 & 0.015 & 0.021 \\
\hline 2 & 0.025 & -0.001 & 0.037 & 0.019 \\
\hline 3 & 0.029 & -0.001 & 0.043 & 0.019 \\
\hline 4 & 0.031 & -0.001 & 0.043 & 0.020 \\
\hline 5 & 0.031 & 0.000 & 0.043 & 0.020 \\
\hline 6 & 0.031 & 0.000 & 0.042 & 0.021 \\
\hline 7 & 0.031 & 0.000 & 0.041 & 0.021 \\
\hline 8 & 0.030 & 0.000 & 0.040 & 0.021 \\
\hline 9 & 0.030 & 0.000 & 0.040 & 0.022 \\
\hline 10 & 0.030 & 0.000 & 0.039 & 0.022 \\
\hline 11 & 0.029 & 0.001 & 0.038 & 0.023 \\
\hline 12 & 0.029 & 0.001 & 0.038 & 0.023 \\
\hline 13 & 0.029 & 0.001 & 0.037 & 0.023 \\
\hline 14 & 0.029 & 0.001 & 0.036 & 0.024 \\
\hline 15 & 0.028 & 0.001 & 0.036 & 0.024 \\
\hline 16 & 0.028 & 0.001 & 0.035 & 0.024 \\
\hline 17 & 0.028 & 0.001 & 0.035 & 0.025 \\
\hline 18 & 0.028 & 0.002 & 0.034 & 0.025 \\
\hline 19 & 0.027 & 0.002 & 0.033 & 0.026 \\
\hline 20 & 0.027 & 0.002 & 0.033 & 0.026 \\
\hline
\end{tabular}

logarithms of manufacturing output (XM), exports (X), imports (IM), and foreign GDP (XF) were included in a preliminary estimate. Most of the variables in this cointegration equation estimate are not significant. The measure with the smallest $t$-statistic is foreign real GDP. A test for restricting the coefficient on foreign real GDP to zero cannot be rejected (chi-squared statistic equals 0.61 , insignificant at the 60.8 percent level), so it was dropped. The same insignificance of most remaining coefficients in the cointegration equation still occurs, so the measure with the smallest $t$-statistic, real GDP, was dropped next based on the same test of the restriction on its coefficient to equal zero (chi-squared statistic equals 0.95 , insignificant at the 85 percent level). Finally, the export variable was dropped for the same reason (chi-squared statistic equals 0.85 , insignificant at the 85 percent level).

The resulting cointegration equation is shown in Table 3 . The trace statistic for the hypothesis of no cointegration is 23.04 , which rejects the hypothesis at the 2.02 percent significance level. Similarly, the maximum eigenvalue statistic of 16.30 rejects the absence of cointegration at the 4.3 percent significance level. The cointegrating equation indicates that a 1-percentage-point rise in imports is associated with a 0.4-percentage-point rise in manufacturing output in the long run, much larger than shown in Table 1. 


\section{Kliesen and Tatom}

An impulse response function shows the effect that a 1-standard deviation shock in one measure has on itself or another variable. Table 4 shows this for the estimates in Table 3 . The "Response of manufacturing output (XM)" columns show the effects of a 1-standard deviation shock to manufacturing output and to imports on manufacturing output for the next 20 quarters. The "Response of imports (IM)" columns show the response of imports to a 1-standard deviation shock to manufacturing output and imports for the next 20 quarters. Entries in the table must be multiplied by 100 to obtain percentage-point effects. The first column in the table shows the effect of a shock to manufacturing output on itself over the subsequent 5 years. The peak effect of the shock to manufacturing output on manufacturing growth occurs at five quarters when output growth is boosted to 3.1 percent $(100 \times 0.031)$. Even after 5 years the effect persists, though it is declining. There is little effect on manufacturing output from a positive shock to imports for the next four quarters (second column). Subsequently, manufacturing output is higher for the remainder of the 5 years, peaking at 0.2 percent after 20 quarters but still rising slowly toward its long-run effect. This confirms the conclusions in Tables 1 and 2 that a shock to imports will not reduce manufacturing output; instead, it boosts manufacturing output.

The response of imports to a positive shock to manufacturing output (third column) is positive, relatively large, and it only returns to its long-run effect slowly. A shock to manufacturing output boosts imports by a peak rate of about 4.3 percent after four quarters, and the effect declines to about 3.3 percent after 5 years. The estimates show the strong effect of a positive shock to manufacturing output on imports. The effect of a 1-standard deviation shock to imports builds slowly from 1 to 5 years later. At the end of 5 years, imports have been boosted by 2.6 percent. The dynamics in both cases show that imports and manufacturing output have a strong positive relationship that persists for over 5 years, leaving a relatively large positive long-run effect.

The Johansen cointegration method is useful for testing for long-run relationships between variables in a context where endogeneity exists among the variables. Its application here confirms the long-run positive relationship between manufacturing output and imports.

\section{CONCLUSION}

U.S. manufacturing suffered a massive decline during the recession in 2008-09, but it has made an impressive comeback. Unfortunately, the same cannot be said for manufacturing employment. Behind the recent trends is relatively rapid manufacturing productivity growth; this growth could have led to dramatic gains in output with unchanged employment, but manufacturing demand is not as responsive to gains in income. The income gains from manufacturing productivity growth boost demand for manufacturing output relatively less than the demand for services. Thus, most of the gains appear in services output and employment with a relatively smaller rise in manufacturing output. As a result, manufacturing employment is displaced to produce services that are relatively more in demand as a result of manufacturing-led economic growth. The same phenomenon has characterized agricultural development for over a century.

In the 1980s, these developments were referred to as the "deindustrialization" of America and the "hollowing out" of the U.S. manufacturing industry. Much of the blame was laid on outsourcing and offshoring to foreign subsidiaries and foreign firms. In fact, Tatom (1988) explains that the 1980s were characterized by a boom in manufacturing output and productivity that led 
economic growth in general and led demand for manufactured goods to outpace capacity growth in manufacturing. As a result, imports boomed along with domestic manufacturing output. The same has been true in the past decade. In recent years, the weakness of manufacturing employment, especially during the recession, has rekindled passions about the death of manufacturing. Continuing globalization has led critics to once again seize on international forces as both the culprit (imports) and the potential solution (increased exports) to the manufacturing problem.

Several other trends in manufacturing continue to be important factors in understanding recent developments. Manufacturing is dominated by some very large firms: Fewer than 10 percent of firms control almost 90 percent of manufacturing assets. Nonetheless, about 45 percent of the estimated 137,770 manufacturing firms have less than $\$ 10$ million in assets. Output remains very volatile, especially in the durable goods sector where demand is readily postponed during recessions and resumed in expansions. This is less the case in nondurable manufacturing and usually barely noticeable in service industries.

The unusually strong performance of manufacturing productivity has largely been the result of rising total factor productivity and relatively rapid growth in the capital-to-labor ratio in manufacturing. Both have accelerated since 1995 and increased even further in the latest recession, recovery, and expansion. Evidence here also shows the expected positive link between strong productivity growth, the relatively high real rates of return across the manufacturing sector, and the deepening of capital per worker or per labor hour.

Our analysis focuses on the role of exports and imports in affecting manufacturing performance. Surprisingly, we find that imports have played a critical positive role in boosting manufacturing output in the United States-much more so, in fact, than exports. We find no discernible influence of export growth on manufacturing growth, but there is a strong positive influence of import growth on manufacturing growth. Many industry, labor, and political leaders believe that boosting manufacturing growth will require limiting imports through favorable preferences for domestic purchasing and raw material and capital goods sourcing, perhaps through quotas, tariffs, domestic content legislation, or simply discriminatory preferences. However, reliance on imports has been a strong positive influence on manufacturing output and productivity. Moreover, there is no discernible gain to manufacturing growth that could arise from new policies proposed to boost exports.

We present causality tests indicating that neither imports nor exports cause manufacturing growth. Instead, both exports and imports are led systematically by prior growth in manufacturing. Thus in the recent recession, a large subsequent decline in imports and exports should not have been a surprise. The importance of imports to domestic manufacturing performance cannot be overstated. Goods imports equal more than 100 percent of manufacturing value added, so they account for more than half of the gross output and sales of domestically produced products. Intermediate goods imports and capital goods imports are the lifeblood of U.S. output. Exports account for a much smaller share of manufacturing value added. While development of foreign markets offers an opportunity for outsized growth, the success of manufacturing has not been as critically dependent on new markets for sales as for new markets for materials and capital goods. 


\section{Kliesen and Tatom}

\section{NOTES}

1 Bartlett and Steele (2012) argue that government policy has been responsible for the decline in manufacturing. They call for more protective actions to reduce imports of manufactured goods.

$\underline{2}$ See Bordo and Haubrich (2012).

3 See chapter 5 of the 2012 Economic Report of the President, which discusses the Obama administration's 2010 National Export Initiative. The goal of this initiative is to double U.S. exports of goods and services from 2010 to 2015.

4 See the summary of a 2001 McKinsey Global Institute study at www.mckinsey.com/insights/mgi/research/ productivity competitiveness and growth/us productivity growth 1995-2000.

5 See Table N of the 2012:Q1 QFR.

6 Assets reported on the consolidated balance sheet. Values for Boeing and Caterpillar are derived from their company Form 10-K annual reports to the Securities and Exchange Commission. See www.sec.gov/Archives/edgar/data/12927/000119312511028490/d10k.htm and www.caterpillar.com/cda/files/2652288/7/2010+10K.pdf.

$\underline{7}$ These issues are discussed in Anderson and Kliesen (2006).

8 These data are reported by the Bureau of Labor Statistics.

9 See Kliesen and Poole (2000).

10 Unless noted otherwise, manufacturing output in this article is measured by the index of industrial production for the manufacturing sector. This series is calculated and published by the Board of Governors of the Federal Reserve System in its G.17 (Industrial Production and Capacity Utilization) statistical release.

11 According to the BEA, "other industries" consists of agriculture, forestry, fishing, and hunting; transportation and warehousing; information; rental and leasing services and lessors of intangible assets; professional, scientific, and technical services; administrative and waste management services; educational services; health care and social assistance; arts, entertainment, and recreation; accommodation and food services; and other services, except government. See Hodge et al. (2011).

12 See the 787 Dreamliner Program Fact Sheet at www.boeing.com/commercial/787family/programfacts.html.

$\underline{13}$ See the suppliers for the Dreamliner at www.airframer.com/aircraft detail.html?model=B787.

14 Many analysts have pointed out the deficiencies of currency depreciation in improving current account imbalances. For example, see McKinnon (2005) and Tatom (2007).

15 See endnote 10. Much of the data for this analysis can be found in the St. Louis Fed's FRED database: http://research.stlouisfed.org/fred2/.

16 See Anderson and Kliesen (2006) for a discussion.

\section{REFERENCES}

Anderson, Richard G. and Kliesen, Kevin L. "The 1990s Acceleration in Labor Productivity: Causes and Measurement." Federal Reserve Bank of St. Louis Review, May/June 2006, 88(3) pp. 181-202; http://research.stlouisfed.org/publications/review/06/05/Anderson.pdf.

Bartlett, Donald L. and Steele, James B. The Betrayal of the American Dream. New York: PublicAffairs, 2012.

Bordo, Michael D. and Haubrich, Joseph G. “Deep Recessions, Fast Recoveries, and Financial Crises: Evidence from the American Record." Federal Reserve Bank of Cleveland Working Paper No. 12-14, June 2012; www.clevelandfed.org/research/workpaper/2012/wp1214.pdf.

Economic Report of the President. Washington, DC: United States Government Printing Office, 2012; www.whitehouse.gov/administration/eop/cea/economic-report-of-the-President.

Eldridge, Lucy P. and Harper, Michael J. "Effects of Imported Intermediate Inputs on Productivity." Monthly Labor Review, June 2010, pp. 3-15; www.bls.gov/opub/mlr/2010/06/art1full.pdf. 
Kliesen and Tatom

Hodge, Andrew W.; Corea, Robert J.; Green, James M. and Retus, Bonnie A. “Returns for Domestic Nonfinancial Business." Survey of Current Business, Bureau of Economic Analysis, June 2011, pp. 24-28; http://bea.gov/scb/pdf/2011/06\%20June/0611 domestic.pdf.

Houseman, Susan; Kurz, Christopher; Lengermann, Paul and Benjamin Mandel. "Offshoring Bias in U.S. Manufacturing." Journal of Economic Perspectives, 25(2) 2011, pp. 111-32; www.brmandel.com/uploads/3/2/4/5/3245755/jep.25.2.pdf.

Kliesen, Kevin L. and Poole, William. "Agricultural Outcomes and Monetary Policy Actions: Kissin' Cousins?" Federal Reserve Bank of St. Louis Review, May/June 2000, 82(3) pp. 1-12; http://research.stlouisfed.org/publications/review/00/05/05kk.pdf.

McKinnon, Ronald I. “Currency Wars.” Wall Street Journal, July 29, 2005; www.stanford.edu/ mckinnon/briefs/CurrencyWars.pdf.

Tatom, John A. "The Link Between the Value of the Dollar, U.S. Trade and Manufacturing Output: Some Recent Evidence." Federal Reserve Bank of St. Louis Review, November/December 1988, pp. 24-37; http://research.stlouisfed.org/publications/review/88/11/Link Nov Dec1988.pdf.

Tatom, John A. "The US-China Currency Dispute: Is a Rise in the Yuan Necessary, Inevitable or Desirable?" Global Economy Journal, 2007, 7(3), Article 2. 
